Article Review

\title{
Healthy Indonesia Program and Family Role in Dealing with Covid-19 In Indonesia
}

\author{
Ismunandar*1, Fahmi Hafid ${ }^{1}$, Taqwin ${ }^{1}$, Zainul ${ }^{1}$, Junaidi ${ }^{1}$, Nasrul ${ }^{1}$ \\ ${ }^{1}$ Poltekkes Kemenkes Palu, Indonesia
}

(*ners.nandar@gmail.com)

\begin{abstract}
The Healthy Indonesia Program with a Family Approach (PIS-PK) aims to improve the quality of life of Indonesian citizens from the smallest unit of society, namely the family. This program is the family's main capital in dealing with the COVID-19 pandemic. The purpose of this study was to assess the potential of the Healthy Indonesia program and the role of families in dealing with Covid-19 in Indonesia. Literature review was conducted during 27 July 2021 to 07 August 2021, and literature search used Publish or Perish software for the time period of 2020-2021. Search keywords include: Coronavirus, Vaccines, Covid-19, Healthy Indonesia Program, Family Planning, delivery in health facilities, complete basic immunization, Exclusive Breastfeeding, growth monitoring, pulmonary tuberculosis, hypertension, mental disorders, smoking, National Health Insurance, access to clean water facilities and healthy latrines. Study findings showed that family planning services, delivery in health facilities, complete basic immunization, and growth monitoring could still be implemented by families in Indonesia. Likewise, the treatment of tuberculosis, hypertension, mental disorders is carried out on a limited basis. The behavior of exclusive breastfeeding, no smoking family members, families which have become members of the National Health Insurance and families which have access to clean water facilities are family capital in dealing with the covid-19 pandemic. In conclusion, the more complete the status of a healthy family based on 12 indicators, the more resilient each family will be in dealing the covid-19 pandemic.
\end{abstract}

Keywords : Healthy Indonesia Program, Family, Covid-19

https://doi.org/10.33860/jik.v15i3.684

(C) 2021 by the authors. Submitted for possible open access publication under the terms and conditions of the Creative

Commons Attribution (CC BY SA) license (https://creativecommons.org/licenses/by-sa/4.0/).

\section{INTRODUCTION}

Coronavirus Diseases (Covid-19) first appeared in Wuhan City, China at the end of 2019 which then spread to various countries including Indonesia and became a global pandemic. ${ }^{1,2}$. Human-to-human transmission has been identified through droplets, hands or contaminated surfaces with an incubation period of 2-14 days ${ }^{3}$. Covid-19 infection cannot occur in the absence of contact. Ways to reduce Covid-19 infection with standard prevention recommended by public health include washing hands, avoiding touching the face and keeping a distance ${ }^{2}$. Public knowledge about hand washing is very important in preventing the spread of Covid19 disease ${ }^{2,4-11}$. Over time, the prevention program was then upgraded to the $5 \mathrm{M}$ movement. The $5 \mathrm{M}$ movement stands for wearing a mask, washing hands \& maintaining distance, reducing mobility and staying away from crowds. The $5 \mathrm{M}$ movement is a movement initiated by the government in order to break the chain of virus spread. This movement is a continuation of the $3 \mathrm{M} \& 3 \mathrm{~T}$ movement, $3 \mathrm{M}$ includes wearing masks, washing hands, and maintaining distance, while $3 \mathrm{~T}$ is a follow-up movement if confirmed positive which includes testing, tracing, and treatment. The $3 \mathrm{M} \& 3 \mathrm{~T}$ movement was echoed by the government which started at the beginning of the pandemic ${ }^{12}$. This movement is carried out at the government level ${ }^{12}$ society ${ }^{13-15}$ and family ${ }^{16-19}$. 
The socialization of this movement has had a positive impact until the end of the first quarter of $2021^{12}$.

The positive side of the COVID-19 pandemic is that the role of the family is becoming increasingly important. Families can give each other understanding, remind each other to stay at home and obey government rules ${ }^{20}$. Family functions in the COVID-19 pandemic include affective functions; by providing opportunities for heads of families or family members to learn and teach $5 \mathrm{M}$ in an effort to prevent the transmission of covid- 19 . The function of socialization is how family members interact with each other in the home, family with neighbors, family with relatives, family to community and family to government. The "new normal" life must be adapted by every family member to stay socialized in a new way in a pandemic situation. Reproductive functions can still be carried out in a pandemic, the role of the BKKBN and reproductive health services can still take place with strict procedures. However, the economic function of the family is changing a lot. The economic function to meet the needs of the family is much reduced for the lower middle-class people who depend on work outside the home for a living. The function of health care or maintenance will increase, especially for family members who undergo independent isolation.

The Healthy Indonesia Program with a Family Approach (PIS-PK) aims to improve the quality of life of Indonesian citizens starting from the family. This program has 12 indicators to increase awareness, willingness and ability to live a healthy life for every family with healthy living behavior and a healthy environment, have the ability to reach quality health services, and have the highest degree of health. ${ }^{21}$. The higher the status of a healthy family based on 12 indicators, the more resilient each family will be in dealing with the COVID-19 pandemic. Exclusive breastfeeding behavior, no smoking family member, families which are already members of JKN, families which have access to clean water facilities 22 and other health behaviors are capital in dealing with the covid19 pandemic.

This study aims to assess the potential of the healthy Indonesia program and the role of families in dealing with Covid-19 in Indonesia.

\section{METHOD}

Literature review was conducted during 27 July 2021 to 07 August 2021, and literature search used Publish or Perish software for the time period of 2020-2021. Search keywords include: Coronavirus, Vaccines, Covid-19, Healthy Indonesia Program, Family Planning, delivery in health facilities, complete basic immunization, Exclusive Breastfeeding, growth monitoring, pulmonary tuberculosis, hypertension, mental disorders, smoking, National Health Insurance, access to clean water facilities and healthy latrines.

\section{RESULTS \& DISCUSSION}

Family is a core family unit (father, mother and children) as stated in the Family Card. To state that a family is healthy or not, a number of markers or indicators are used. In the context of implementing the Healthy Indonesia Program, it has been agreed that there are 12 main indicators to mark the health status of a family. The twelve main indicators are; (1) Families participate in the Family Planning program, (2) Mothers give birth in health facilities (3) Infants receive complete basic immunizations, (4) Infants receive exclusive breastfeeding, (5) Toddlers receive growth monitoring, (6) Tuberculosis sufferers lungs get treatment according to standards, (7) hypertension sufferers take regular treatment, (8) mental disorders get treatment and are not neglected, (9) no family members smoke, (10) the family is already a member of the National Health Insurance (JKN). ), (11) Families have access to clean water facilities, (12) Families have access to or use healthy latrines ${ }^{22}$.

In the implementation of PIS-PK during the pandemic, Yolandari's findings (2020) showed that family visits and data collection in one Public Health Center working area could not be continued due to the Covid-19 pandemic. Even though the officers were committed, they found obstacles in the form of limited quantity and quality of human resources, delays in budgeted funds, limited facilities and infrastructure, availability of healthy family information packages (Pinkesga) and healthy family applications that were difficult to access. ${ }^{21}$. One of the solutions offered by Aliyanto (2021) in reaching families during the pandemic is the use of SIPISPeKa. This telehealth media is declared feasible in terms of telehealth media 
rules, governance, web-based communication media and relevance to the PIS-PK program ${ }^{23}$.

The COVID-19 pandemic has greatly impacted the sustainability of public health services, including family planning services. In the family planning service guidelines, it is written an appeal to delay pregnancy during the pandemic and recommends family planning acceptors not to come to health workers unless they have complaints. This study captures the response to adjustments to family planning services during the COVID-19 pandemic. The policy for adjusting family planning services during the COVID-19 pandemic was issued two months after the Government established an emergency condition, causing service uncertainty in the initial phase. According to predictions, there has been a decrease in visits by family planning acceptors at the Public Health Center with a range of $30 \%-50 \%$. Family Planning program and IUD injection services themselves are still carried out at the Puskesmas through a patient visit scheduling mechanism. Adjustment of family planning services has been running in health facilities, as an effort to maintain the sustainability of the program during the pandemic, PMB, cadres, and family planning instructors have made a strong contribution to supporting Pubic Health Center in service implementation. ${ }^{24}$. In Yogyakarta, it was reported that the number of active and new contraceptive use at the beginning of the Covid-19 pandemic had decreased. The number of new family planning participants appears to have decreased in March-April 2020 along with the addition of the number of positive cases of Covid-19 in the Special Region of Yogyakarta. This is due to the decreased intensity of family planning counseling and services ${ }^{25}$. As a solution, Mandira (2020) provides education to family planning participants using zoom media, targeting female participants of childbearing age $^{26}$.

The Indonesian government through the website covid-19.go.id has disseminated guidelines for pregnant women during the outbreak. Health workers in collaboration with other experts need to develop online psychological treatment services using WhatsApp, Google Meet, Zoom Cloud Meetings, and other applications ${ }^{27}$. One way to respond to childbirth in health facilities during a pandemic is by community service activities "birth preparation education with health protocols in the new normal period as an effort to prevent Covid-19 and to increase knowledge of pregnant women about preparation for childbirth during the Covid-19 pandemic" ${ }^{28}$. Health education about preparation for pregnancy and childbirth in the midst of the Covid-19 pandemic and consultation via WhatsApp group. Midwives as health workers also provide virtual health education ${ }^{29}$.

This pandemic has an impact on the complete basic immunization program at the Puskesmas level. One of them is the Tempel I Health Center in Sleman Regency, the coverage decreased by $26 \%{ }^{30}$. Parents are also worried about going to the health care center for fear of COVID-19 infection ${ }^{31}$. Nevertheless, health education regarding complete basic immunization during the Covid pandemic is still carried out, such as in Kelebuh Village, Batunyala Health Center Working Area ${ }^{32}$. Health education about basic immunization complete with educative video media can also be an alternative during the COVID-19 pandemic ${ }^{33}$.

Evayani's study (2021) shows $76.6 \%$ of exclusive breastfeeding during the Covid-19 pandemic in Loaddem Village ${ }^{34}$. One way to increase the capacity of breastfeeding mothers is through health education regarding exclusive breastfeeding during the Covid-19 pandemic ${ }^{35}$. Community service activities are carried out in the form of mentoring cadres and health workers for breastfeeding mothers carried out in the Sipatana Health Center area. Information for breastfeeding mothers about breast milk and its problems through the Breastfeeding manual 36.

Sari's study (2020) shows that most of the sources of mother's knowledge about complementary feeding are obtained from electronic social media (38.7\%) and advanced health services $(37.3 \%)$. A total of $46.7 \%$ of mothers use the MCH handbook to monitor the growth of under-fives and $14.7 \%$ of mothers have used the Primaku application ${ }^{37}$. The implementation of health education monitoring the growth and development of Toddlers during the Covid-19 pandemic in the work area of the Balekambang Bogor Health Center has also been carried out as a form of community service 38 .

Survey data describes multidrug-resistant tuberculosis, characteristics of tuberculosis patients and stress resistance during the Covid19 pandemic in West Sumatra Province ${ }^{39}$. 
Wulandari's study (2021) shows that the level of knowledge of TB sufferers about COVID-19 prevention is mostly in the good category $58 \%$ and the attitude of patients about COVID-19 prevention is mostly in the sufficient category $53.4 \%$, as well as the behavior of patients about COVID-19 prevention. 19 are mostly in the sufficient category $48.9 \%{ }^{40}$.

Patients with hypertension who take the Renin-Angiotensin-Aldosterone System inhibitor have a higher risk of being infected with the SARS-Cov-2 virus because of the expression of ACE2. Overexpression of ACE2 can make it easier for SARS-CoV-2 to enter the body ${ }^{41}$. Hypertension is a disease that is closely related to behavior and lifestyle, so that its treatment is by changing healthy living behavior. The results of Susanti's study (2021) show "Ingenious Behavior of Hypertension Patients During the Covid 19 Pandemic". SMART behaviors include: Routine health checks, Get rid of cigarette smoke, Physical activity, Healthy diet, Rest, manage stress ${ }^{42}$. Efforts to prevent hypertension are: positive thinking, diligent in worship or other spiritual activities, then exercising regularly and avoiding foods that contain lots of salt and cholesterol $^{43}$.

Literature related to people with mental disorders and their treatment during the Covid19 period in Indonesia has not been found. Mental health problems, such as anxiety, depression, and trauma due to Covid-19 are felt by most Indonesians. Some of the main risk factors are social distance and isolation, economic recession, stress and trauma to health workers, and stigma and discrimination ${ }^{44}$. When it comes to mental health, there are various mental health responses in a pandemic outbreak. People's thought processes, behavior and emotional responses to outbreaks vary greatly according to their own background and the community in which they live. For some people, misinformation, uncertainty, and fear of contagion can increase stress and panic ${ }^{45}$. Study on students of the general practitioner education study program and medical professional education during the Covid-19 pandemic, it turns out that respondents who experience symptoms of emotional mental disorders are $68.7 \%$, mild to very severe depression symptoms are $57.1 \%$ and mild to very severe anxiety symptoms. severe amounted to $73.6 \%$ 46.

By quitting smoking, people can increase their body's immunity to fight Covid-19 ${ }^{47}$. Covid-19 patients who had a smoking habit before the pandemic were potentially 2 times more likely to experience worsening of symptoms, an increased chance of being admitted to the ICU and even death than patients who did not smoke. ${ }^{48}$. Ruhyat's study (2021) on smoking behavior during the COVID-19 pandemic showed $39.3 \%$ smoked at home, $13.4 \%$ smoked at work and $47.3 \%$ said smoking elsewhere ${ }^{49}$. Covid-19 can influence sufferers to reduce and even stop smoking ${ }^{50}$.

Globally families have postponed or canceled healthcare visits in response to the Covid-19 pandemic resulting in temporary reductions in healthcare spending. Primary care visits by JKN members in Indonesia decreased by $28 \%$ in 2020 compared to the projected volume of counterfactual visits. Inpatient claims decreased by $37 \%$ and outpatient claims decreased by $36 \%$. Health service visits in Indonesia have decreased due to Covid-19 ${ }^{51}$. Sparrow (2020) predicts this pandemic undermines the long-term financial sustainability of Indonesia's social health insurance system ${ }^{52}$. However, in the midst of this decline, there are still JKN participants who use health services such as at the Padang Health Center ${ }^{53}$.

During the Covid-19 pandemic, clean water consumption increased and there was a change in people's behavior to live a cleaner life 54. One of the educational activities for providing clean water facilities to support the application of holistic hygiene patterns in maternal and child health in the Covid-19 emergency era has been carried out in Musi Banyuasin Regency ${ }^{55}$. The existence of the Covid-19 pandemic has actually become an opportunity to prioritize clean water as a sector that needs to be a priority because of its role as the front line in preventing the spread of Covid$19^{56}$.

Covid-19 transmission does not only occur through nasal or oral droplets, but also through human feces infected with the virus. This condition requires the public to maintain the cleanliness of both private and public toilets to avoid the risk of transmission of Covid-19. The factors that cause many people to open defecation in Surakarta are not having latrines or not having the funds to build them; limited access to clean water; live in densely populated urban settlements. The community-based total sanitation approach emerged as the 
government's response to optimize latrine hygiene by the community ${ }^{57}$.

The role of the family is an important factor in compliance with Healthy Indonesia health programs. Families build and maintain a very basic healthy lifestyle. Family freedom in preserving the lifestyle and health of family members is strongly influenced by structures outside the family itself. Building a healthy family takes time, effort, knowledge, and skills. The idea of health in the family is very dependent on time, the people involved, the function considered, gender, and social category, which means that social and political issues will also be related to the health that is built in the family. Sharing Covid-19 information with family members is a partial mediator between individual health literacy and personal preventive behavior against Covid-19. Strategies to improve health literacy and preventive measures against Covid-19 are needed to promote family well-being during the pandemic ${ }^{58}$.

The role of the family in preventing the transmission of Covid-19 in Indonesia can be done by; Families are the right source of information about Covid-19 and its prevention, Families who practice a healthy lifestyle better the number of Covid-19 cases is low ${ }^{59}$. The family is an independent treatment room in selfisolation conditions and is an optimistic encouragement to be able to avoid Covid-19 by making various changes to a healthier lifestyle ${ }^{60}$. Families learn to use the yard to grow vegetables and family medicinal plants ${ }^{61}$. Increased family awareness of alternative medicine such as the use of ginger and how to grow ginger ${ }^{62}$.

Riyanto et al (2021) reported on a healthy lifestyle in the new normal era of Covid-19 in Indonesia, involving 3349 respondents and analyzing eight components of a healthy lifestyle including physical activity, a balanced diet, consumption of fruits and vegetables, washing hands, wearing masks, social distancing. physical activity, avoiding crowds, and staying at home. The results showed that the respondents in the older age group and women had better healthy lifestyles. Respondents with secondary and higher education levels are better at eating a balanced diet, washing hands, wearing masks, doing physical distancing, and avoiding crowds. Entrepreneurs are better off doing physical activity, consuming a balanced diet, enough fruits and vegetables. civil servants, soldiers or police have more responsibility to wear masks and wash their hands. Farmers, fishermen, or drivers have done better physical activity, but they find it difficult to stay at home. In addition, health workers have performed all components of a healthy lifestyle better. Judging from the area, provinces with low-moderate number of Covid19 cases have practiced a healthy lifestyle better 59.

Gunadi's findings (2021) reported that members of the same family may show different disease outcomes ${ }^{63}$. Soedarsono (2020) reported that people without symptoms still have the potential to transmit the virus. different laboratory findings and clinical manifestations of family clusters of Covid-19 cases in Indonesia ${ }^{64}$. Appropriate and effective risk communication is needed to respond to the Covid-19 pandemic ${ }^{65}$. A consequence of poor risk communication and increased risk perception is hoarding behavior, which can lead to a lack of medicines and personal protective equipment ${ }^{66}$. Higher education as an agent of change is expected to be an actor in the prevention of Covid-19 risk communication interventions in universities such as the dissemination of educational information communication media about Covid-19 ${ }^{67}$. One example of the use of virtual communication in an effort to prevent covid 19 is the use of information and communication technology in the Halodoc application as a telemedicine check for Covid-19 in an effort to prevent the spread of the corona virus. ${ }^{68}$. The next challenge is about the Covid-19 vaccination. Acceptance of the Covid-19 vaccine is strongly influenced by the basic effectiveness of the vaccine ${ }^{69}$. Respondents in Central Sulawesi who are willing to receive the Covid-19 vaccination are $35.3 \%$ with the determinants of age and religion ${ }^{70}$. The wrong public perception about Covid-19 vaccination is caused by a lack of understanding from the public. This wrong perception arises because of the lack of good communication from the authorities such as health workers to convince the public about the effectiveness of the Covid-19 vaccine. ${ }^{71}$. Willingness to pay for Covid-19 vaccines is relatively high in Indonesia, to achieve higher vaccine coverage, it may be necessary to partially subsidize vaccines for the underprivileged and design health promotion materials to improve perceptions of Covid-19 risk in Indonesia ${ }^{72}$. 


\section{CONCLUSION}

The more complete the status of a healthy family based on 12 indicators, the more resilient each family will be in facing the COVID-19 pandemic. Exclusive breastfeeding behavior, No family members smoke, Families are already members of the National Health Insurance (JKN), Families have access to clean water facilities and latrines and other health behaviors are capital in dealing with the COVID-19 pandemic. Health workers communicate well to the public about the safety and effectiveness of the Covid-19 vaccine.

\section{ACKNOWLEDGEMENT}

Authors thank the Director of Health Polytechnic, Ministry of Health, Palu, Head of the Center for Research and Community Service of Health Polytechnic of Ministry of Health Palu

\section{REFERENCES}

1. WHO. Coronavirus disease (COVID-19) Pandemic [Internet]. WHO. 2020 [cited 2020 Apr 29]. p. 1. Available from: https://www.who.int/emergencies/diseases/ novel-coronavirus-2019

2. Grech V. Unknown unknowns - COVID-19 and potential global mortality. Early Hum Dev. 2020 Mar;144:105026.

3. Zhai P, Ding Y, Wu X, Long J, Zhong Y, Li $Y$. The epidemiology, diagnosis and treatment of COVID-19. Int J Antimicrob Agents. 2020 Mar; 105955.

4. WHO. WHO | Clean hands protect against infection [Internet]. WHO. 2020 [cited 2020 Apr 29]. p. 1. Available from: https://www.who.int/gpsc/clean_hands_prot ection/en/

5. Chen X, Ran L, Liu Q, Hu Q, Du X, Tan X. Hand Hygiene, Mask-Wearing Behaviors and Its Associated Factors during the COVID-19 Epidemic: A Cross-Sectional Study among Primary School Students in Wuhan, China. Int J Environ Res Public Health. 2020 Apr;17(8).

6. Lin Y-H, Liu C-H, Chiu Y-C. Google searches for the keywords of "wash hands" predict the speed of national spread of COVID-19 outbreak among 21 countries. Brain Behav Immun. 2020 Apr;

7. Sun J, Shi Z, Xu H. Non-pharmaceutical interventions used for COVID-19 had a major impact on reducing influenza in China in 2020. J Travel Med. 2020 Apr;

8. Gupta MK, Lipner SR. Personal Protective Equipment Recommendations Based on
COVID-19 Route of Transmission. Journal of the American Academy of Dermatology. 2020.

9. Morawska L, Cao J. Airborne transmission of SARS-CoV-2: The world should face the reality. Environ Int. 2020 Apr;139:105730.

10. Jones L, Walsh K, Willcox M, Morgan P, Nichols J. The COVID-19 pandemic: Important considerations for contact lens practitioners. Cont Lens Anterior Eye. 2020 Apr;

11. Chavez S, Long B, Koyfman A, Liang SY. Coronavirus Disease (COVID-19): A primer for emergency physicians. Am J Emerg Med. 2020 Mar;

12. Saiful R, Abhipraya FA. Efektivitas Pemerintah dalam Sosialisasi Gerakan 5M Kepada Masyarakat. War Governare J Ilmu Pemerintah [Internet]. 2021;2(1). Available from:

https://www.journal.unwira.ac.id/index.php /WG/article/view/1147

13. Gustami A, Yulima S, Rembulan N. Analisis Penerapan 5M dan Vaksinasi Dalam Meningkatkan Kesadaran Diri Masyarakat Saat Pandemi Covid-19 Di Desa Limbung. J Abdimas [Internet]. 2021; Available from: http://jabb.lppmbinabangsa.id/index.php/ja $\mathrm{bb} /$ article/view/77

14. Purwanti NWE. Gambaran Perilaku 5M Penecegahan Covid-19 pada Masyarakat di Desa Keramas Kecamatan Blahbatuh Kabupaten Gianyar [Internet]. repository.poltekkes-denpasar.ac.id; 2021. Available from: http://repository.poltekkesdenpasar.ac.id/7251/

15. Ria Ramadhani Dwi Atmaja, Riskiyana, Alif Firman Firdausy, Syanindita Puspa Wardhani, Yuyun Yueniwati. Socialization of $5 \mathrm{M}$ implementation and independent isolation for patients with Covid-19 based on online media for the residents of Semanding Hamlet, Sumbersekar Village, Malang Regency. World J Adv Res Rev [Internet]. 2021 Apr 30;10(1):115-24. Available from: https://wjarr.com/content/socialization-5mimplementation-and-independent-isolationpatients-covid-19-based-online

16. Andayani N. Gambaran Pengetahuan 5M Pencegahan Covid-19 Pada Keluarga di Gang Telkom Kelurahan Pedungan Kecamatan Denpasar Selatan Tahun 2021 [Internet]. repository.poltekkesdenpasar.ac.id; 2021. Available from: http://repository.poltekkesdenpasar.ac.id/7164/

17. Apriyanti NPS. Gambaran Kepatuhan 5M Pencegahan Covid-19 Pada Kepala Keluarga di Banjar Pangkung Telepus Desa 
Yehembang Kauh Kecamatan Mendoyo Kabupaten Jembrana Tahun 2021 [Internet]. repository.poltekkes-denpasar.ac.id; 2021. Available from: http://repository.poltekkesdenpasar.ac.id/7199/

18. Pratiwi PMI. Gambaran Kepatuhan 5M Pencegahan Covid-19 pada Keluarga di Gang Lely Desa Batubulan Kecamatan Sukawati Kabupaten Gianyar Tahun 2021 [Internet]. repository.poltekkesdenpasar.ac.id; 2021. Available from: http://repository.poltekkes-

denpasar.ac.id/id/eprint/7165

19. Aulia G, Fahriati AR, Ratnaningtyas TO, Utami SM, Pratiwi RD, Ismaya NA, et al. Edukasi Pencegahan Covid-19 dengan Protokol Kesehatan 5M dan Pentingnya Multivitamin di Masa Pandemi Covid-19. Jam J Abdi Masy [Internet]. 2021;2(1). Available from: http://openjournal.wdh.ac.id/index.php/JA $\mathrm{M} /$ article/view/138

20. Muhid A, Muslimin M. Study Literature: Peranan Komunikasi dalam Keluarga Dimasa Pandemi Covid-19. Hikmah [Internet]. 2020; Available from: http://jurnal.iain-

padangsidimpuan.ac.id/index.php/Hik/articl e/view/2957

21. Yolandari P. Pelaksanaan Program Indonesia Sehat dengan Pendekatan Keluarga di Puskesmas Kedai Durian Kecamatan Medan Johor Tahun 2020 [Internet]. repositori.usu.ac.id; 2021. Available from: http://repositori.usu.ac.id/handle/12345678 9/32791

22. Kemenkes. RI. Program Indonesia Sehat dengan Pendekatan Keluarga - PISPK [Internet]. Kementerian Kesehatan RI. 2017 [cited 2021 Jul 24]. Available from: http://pispk.kemkes.go.id/id/programpispk/pelaksanaan-pendekatan-keluargasehat/

23. Aliyanto W, Suarni L, Sono S, Hajar AI. Pengembangan Telehealth "SIPISPeKa" sebagai Solusi Mensukseskan Program Indonesia Sehat dengan Pendekatan Keluarga (PIS-PK). J Kesehat [Internet]. 2021 Apr 29;12(1):61. Available from: http://ejurnal.poltekkes-

tjk.ac.id/index.php/JK/article/view/2553

24. Soewondo P, Sakti GMK, Rahmayanti NM, Irawati DO, Pujisubekti R, Sumartono AHI, et al. Bagaimana Layanan Keluarga Berencana Respons Terhadap Pandemi Covid-19 Di Indonesia: Studi Kasus Di 8 Kabupaten/Kota. In: Prosiding Forum Ilmiah Tahunan (FIT) IAKMI [Internet]. jurnal.iakmi.id; 2020. Available from:
http://jurnal.iakmi.id/index.php/FITIAKMI/ article/view/87

25. Witono W, Parwodiwiyono S. Kepesertaan Keluarga Berencana Pada Masa Awal Pandemi Covid-19 di Daerah Istimewa Yogyakarta. Pancanaka J Kependudukan, Kel dan Sumber Daya Mns [Internet]. 2020;1(2):77-88. Available from: http://pancanaka.latbangdjogja.web.id/inde x.php/pancanaka/article/view/47

26. Mandira TM, Fitriani D, Ardi N bodro, Veri V, Selvia A. Edukasi Program Keluarga Berencana (KB) Pada Wanita Usia Subur Selama Masa Pandemi Covid 19. Jam J Abdi Masy [Internet]. 2020;1(1). Available from: http://openjournal.wdh.ac.id/index.php/JA $\mathrm{M} /$ article/view/83

27. Ifdil I, Fadli RP, Gusmaliza B, Putri YE. Mortality and psychological stress in pregnant and postnatal women during COVID-19 outbreak in West Sumatra, Indonesia. J Psychosom Obstet Gynecol [Internet]. 2020 Oct 1;41(4):251-2. Available from: https://www.tandfonline.com/doi/full/10.10 80/0167482X.2020.1779216

28. Maya RAA. Edukasi Persiapan Persalinan Dengan Protokol Kesehatan Di Masa Kenormalan Baru (New Normal) Sebagai Upaya Pencegahan Covid-19 Pada Ibu Hamil. Khidmah [Internet]. 2021 Jun 28;3(1):264-9. Available from: https://khidmah.ikestmp.ac.id/index.php/khi $\mathrm{dmah} /$ article/view/342

29. Gustina I. Penyuluhan Kesehatan Pada Ibu Hamil Tentang Mempersiapkan Kehamilan Dan Persalinan Di Tengah Pandemi Covid19. J Pengabdi Masy Bakti Parahita [Internet]. 2020; Available from: http://journal.binawan.ac.id/parahita/article/ view/134

30. Fathahidin GA. Analisis Pelaksanaan Program Imunisasi Dasar Lengkap (Idl) Pada Masa Pandemi Covid-19 Di Puskesmas Tempel I Kabupaten Sleman [Internet]. eprints.undip.ac.id; 2021. Available from: http://eprints.undip.ac.id/83139/

31. Suwantika AA, Boersma C, Postma MJ. The potential impact of COVID-19 pandemic on the immunization performance in Indonesia. Expert Rev Vaccines [Internet]. 2020 Aug 2;19(8):687-90. Available from: https://www.tandfonline.com/doi/full/10.10 80/14760584.2020.1800461

32. Usman A. Penyuluhan Kesehatan Tentang Imunisasi Dasar Lengkap Pada Masa Pandemi Covid 19 di Desa Kelebuh Wilayah Kerja Puskesmas Batunyala. J Community Engagem Heal [Internet]. 2021; Available 
from:

https://jceh.org/index.php/JCEH/article/vie w/133

33. Tarigan PSW. Pengaruh Pendidikan Kesehatan Dengan Media Video Edukatif Terhadap Pengetahuan Ibu Tentang Imunisasi Dasar Lengkap Dimasa Pandemi Covid-19 Di Puskesmas Minas Tahun 2021 [Internet]. repository.pkr.ac.id; 2021. Available from: http://repository.pkr.ac.id/id/eprint/1723

34. Evayani NL. Gambaran Pemberian Asi Eksklusif Pada Ibu Menyusui Dimasa Pandemi Covid-19 Di Desa Bebandem Tahun 2021 Penelitian Ini Dilakukan Di Desa Bebandem Kecamatan Bebandem Kabupaten Karangasem Tahun 2021 [Internet]. repository.poltekkesdenpasar.ac.id; 2021. Available from: http://repository.poltekkes-

denpasar.ac.id/id/eprint/7688

35. Rochmawati R, Kusmintarti A, Fary V, Elfaristo L, Lovita Pembayun E, Hayuningsih S, et al. Meningkatkan Kapasitas Ibu Menyusui Melalui Penyuluhan Kesehatan Mengenai Pemberian ASI Eksklusif Selama Masa Pandemi COVID-19. Sasambo J Abdimas (Journal Community Serv [Internet]. 2021 Jun 1;3(2):76-82. Available from: https://journal-

center.litpam.com/index.php/Sasambo_Abd imas/article/view/427

36. Igirisa Y, Sujawaty S, Yanti FD, Oktaviani A. Pemberdayaan Masyarakat Dalam Upaya Menyukseskan Asi Eksklusif Melalui Pendampingan Ibu Menyusui Pada Masa Pandemi Covid 19. In: Prosiding Seminar Nasional Universitas Respati Yogyakarta [Internet]. prosiding.respati.ac.id; 2020. Available from: http://prosiding.respati.ac.id/index.php/PSN /article/view/307

37. Sari MGK, Widyaningsih V, Wardani MM, Murasmita A, Ghufron AA. Hubungan Pemantauan Pertumbuhan Anak Baduta pada Masa Pandemi COVID-19 dan Pengetahuan Ibu Tentang MP-ASI dengan Status Gizi. SEMAR (Jurnal Ilmu Pengetahuan, Teknol dan Seni bagi Masyarakat) [Internet]. 2021 Mar 31;10(1):70. Available from: https://jurnal.uns.ac.id/jurnalsemar/article/view/46911

38. Dinengsih S, Helen M. Pendidikan Kesehatan Pemantauan Pertumbuhan Dan Perkembangan Balita Pada Masa Pandemi Covid-19 Di Wilayah Kerja Puskesmas Balekambang Bogor Tahun 2020 [Internet]. repository.unas.ac.id. Available from: http://repository.unas.ac.id/2641/

39. Nindrea RD, Sari NP, Harahap WA, Haryono SJ, Kusnanto H, Dwiprahasto I, et al. Survey data of multidrug-resistant tuberculosis, Tuberculosis patients characteristics and stress resilience during COVID-19 pandemic in West Sumatera Province, Indonesia. Data $\mathrm{Br}$ [Internet]. 2020 Oct;32:106293. Available from: https://linkinghub.elsevier.com/retrieve/pii/ S2352340920311872

40. Wulandari S. Hubungan Pengetahuan dan Sikap dengan Perilaku Pencegahan Covid19 pada Penderita Tuberkulosis di Rumah Sakit Paru Jember [Internet]. repository.unmuhjember.ac.id; 2021. Available from: http://repository.unmuhjember.ac.id/id/epri $\mathrm{nt} / 8416$

41. Alfad H, Saftarina F, Kurniawan B. Dampak Infeksi SARS-Cov-2 Terhadap Penderita Hipertensi. J Major [Internet]. 2020; Available from: http://juke.kedokteran.unila.ac.id/index.php /majority/article/view/2695

42. Susanti Y, Anita A, Santoso DYA. Perilaku Cerdik Penderita Hipertensi Dimasa Pandemi Covid 19. J Keperawatan [Internet]. 2021; Available from: http://journal.stikeskendal.ac.id/index.php/ Keperawatan/article/view/1116

43. Bahtiar H, Ariyanti M. Promosi Kesehatan Tentang Covid-19, Pencegahan Dan Penanganan Hipertensi Pada Lansia. J Lentera [Internet]. 2021; Available from: http://journal.stikesyarsimataram.ac.id/inde x.php/lentera/article/view/89

44. Sihaloho LB. Stress Yang Timbul Di Tengah-tengah Masyarakat, Keluarga, Lansia, Remaja, Perawat, Petugas Kesehatan, Gangguan Jiwa, Pasien Akibat Situasi Pandemic Covid-19. 2021; Available from: https://osf.io/preprints/uz65a/

45. Kaligis F, Indraswari MT, Ismail RI. Stress during COVID-19 pandemic: mental health condition in Indonesia. Med J Indones [Internet]. 2020 Oct 9;29(4):436-41. Available from: https://mji.ui.ac.id/journal/index.php/mji/art icle/view/4640

46. Setiawati Y, Wahyuhadi J, Joestandari F, Maramis MM, Atika A. Anxiety and Resilience of Healthcare Workers During COVID-19 Pandemic in Indonesia. J Multidiscip Healthc [Internet]. 2021 Jan;Volume 14:1-8. Available from: https://www.dovepress.com/anxiety-andresilience-of-healthcare-workers-duringcovid-19-pandemic--peer-reviewed-articleJMDH 
47. Salsabil AA, Santoso MB, Zainudiin M. Penanganan Kebiasaan Merokok Di Masa Pandemi Covid-19. Focus J Pekerj Sos [Internet]. 2020;3(2). Available from: http://journal.unpad.ac.id/focus/article/view $/ 28458$

48. Atmojo JT, Arradini D, Darmayanti AT, Widiyanto A, Handayani RT. Dampak Merokok terhadap Covid-19. J Ilm Permas [Internet]. 2021;11(1). Available from: http://journal.stikeskendal.ac.id/index.php/P SKM/article/view/1143

49. Ruhyat E. Perilaku Merokok di Masa Covid19. Sehat Masada [Internet]. 2021;15(1). Available from: http://ejurnal.stikesdhb.ac.id/index.php/Jsm /article/view/178

50. Sabrina S, Ichsan B. Hubungan Kebiasaan Merokok dan Penderita Covid-19: Studi Literatur. Proceeding of The URECOL [Internet]. 2021; Available from: http://repository.urecol.org/index.php/proce eding/article/view/1439

51. Teplitskaya L, Ward K, Stein DT. Financial Risk Protection in the COVID-19 Pandemic and Recession for Households Insured By Indonesia's Jaminan Kesehatan Nasional [Internet]. Health Economic In A Time of Global Change. healtheconomics.confex.com; 2021. Available from: https://healtheconomics.confex.com/healthe conomics/2021/meetingapp.cgi/Paper/6522

52. Sparrow R, Dartanto $\mathrm{T}$, Hartwig R. Indonesia Under the New Normal: Challenges and the Way Ahead. Bull Indones Econ Stud [Internet]. 2020 Sep 1;56(3):269-99. Available from: https://www.tandfonline.com/doi/full/10.10 80/00074918.2020.1854079

53. Pebriani A, Misnaniarti M. Faktor-Faktor Yang Mempengaruhi Pemanfaatan Pelayanan Kesehatan Bagi Peserta Jkn Di Puskesmas Padang Selasa Palembang Era Covid-19 [Internet]. repository.unsri.ac.id; 2021. Available from: http://repository.unsri.ac.id/id/eprint/47735

54. Suryani AS. Pembangunan Air Bersih dan Sanitasi saat Pandemi Covid-19. Aspir J Masal Sos [Internet]. 2020 Dec 29;11(2):199-214. Available from: http://jurnal.dpr.go.id/index.php/aspirasi/art icle/view/1757

55. Pratama RN. Edukasi Penyediaan Sarana Air Bersih untuk menunjang Penerapan Pola Hygiene Pada Kesehatan Ibu dan Anak Secara Holistic di Era Gawat Darurat Covid 19". Khidmah [Internet]. 2021 Jun 28;3(1):270-7. Available from: http://khidmah.ikestmp.ac.id/index.php/khi dmah/article/view/343

56. Purwanto EW. Pembangunan Akses Air Bersih Pasca Krisis Covid-19. J Perenc Pembang Indones J Dev Plan [Internet]. 2020 Jun 8;4(2):207-14. Available from: https://journal.bappenas.go.id/index.php/jpp /article/view/111

57. Demartoto A, Zunariyah S, Pujihartati SH. The optimization of public toilet maintenance in Covid-19 pandemic era. In: International Conference On Energy, Environment, Epidemiology, And Information System $>$ International Conference On Energy, Environment, Epidemiology, And Information System 2021 [Internet]. Bandung: econference.undip.ac.id; 2021. Available from:

http://www.econference.undip.ac.id/index.p hp/icenis/2021/paper/viewPaper/1545

58. Wong JYH, Wai AKC, Zhao S, Yip F, Lee JJ, Wong CKH, et al. Association of Individual Health Literacy with Preventive Behaviours and Family Well-Being during COVID-19 Pandemic: Mediating Role of Family Information Sharing. Int J Environ Res Public Health [Internet]. 2020 Nov 27;17(23):8838. Available from: https://www.mdpi.com/905104

59. Riyanto S, P Asturiningtyas I, Setianingsih I, Nur'aini N, Zainuddin Z, Purwoko S, et al. Healthy lifestyles during the COVID-19 new normal era in Indonesia. Ann Trop Med Public Heal. 2021;24(01).

60. Atmadja TFA, Yunianto AE, Yuliantini E, Haya M, Faridi A, Suryana S. Gambaran sikap dan gaya hidup sehat masyarakat Indonesia selama pandemi Covid-19. AcTion Aceh Nutr J [Internet]. 2020 Nov 13;5(2):195. Available from: http://ejournal.poltekkesaceh.ac.id/index.ph p/an/article/view/355

61. Pambudi PA. Pandemi Covid-19: Refleksi Pentingnya Optimasi Lahan Pekarangan Sebagai Penyokong Kemandirian Pangan Dan Kesehatan Keluarga. EnviroScienteae [Internet]. 2020 Dec 9;16(3):408. Available from:

https://ppjp.ulm.ac.id/journal/index.php/es/ article/view/9683

62. Rokhmah D, Ali K, Putri SMD, Khoiron K. Increase in public interest concerning alternative medicine during the COVID-19 pandemic in Indonesia: a Google Trends study. F1000Research [Internet]. 2020 Oct 6;9:1201. Available from: https://f1000research.com/articles/91201/v1

63. Gunadi, Wibawa H, Hakim MS, Marcellus, Trisnawati I, Khair R El, et al. Molecular 
epidemiology of SARS-CoV-2 isolated from COVID-19 family clusters. BMC Med Genomics [Internet]. 2021 Dec 1;14(1):144. Available from: https://bmcmedgenomics.biomedcentral.co m/articles/10.1186/s12920-021-00990-3

64. Soedarsono S. A Family Cluster of Coronavirus Disease (COVID-19) Infection with Different Clinical Manifestations. Acta Med Indones [Internet]. 2020;52(2):155-62. Available from: http://www.actamedindones.org/index.php/i jim/article/view/1452

65. Leask J, Hooker C. How risk communication could have reduced controversy about school closures in Australia during the COVID-19 pandemic. Public Heal Res Pract [Internet]. 2020;30(2). Available from: https://www.phrp.com.au/?p=39229

66. Abrams EM, Greenhawt M. Risk Communication During COVID-19. J Allergy Clin Immunol Pract [Internet]. 2020 Jun;8(6):1791-4. Available from: https://linkinghub.elsevier.com/retrieve/pii/ S2213219820303639

67. Kementerian Kesehatan. Pedoman Pencegahan dan Pengendalian Coronavirus Disease (COVID-19). Vol. 1, Direktorat Jenderal Pencegahan dan Pengendalian Penyakit. 2020. 1-125 p.

68. Hanifah M. Pemanfaatan Teknologi Informasi Dan Komunikasi Pada Aplikasi Halodoc Sebagai Telemedicine Check Covid-19 Dalam Upaya Preventif Penyebaran Virus Corona di Sleman Yogyakarta [Internet]. eprints.mercubuanayogya.ac.id; 2020. Available from: http://eprints.mercubuana-

yogya.ac.id/9022/

69. Harapan H, Wagner AL, Yufika A, Winardi W, Anwar S, Gan AK, et al. Acceptance of a COVID-19 Vaccine in Southeast Asia: A Cross-Sectional Study in Indonesia. Front Public Heal [Internet]. 2020 Jul 14;8. Available from: https://www.frontiersin.org/article/10.3389/ fpubh.2020.00381/full

70. Ichsan DS, Hafid F, Ramadhan K, Taqwin T. Determinan Kesediaan Masyarakat menerima Vaksinasi Covid-19 di Sulawesi Tengah. Poltekita J Ilmu Kesehat [Internet]. 2021 May 26;15(1):1-11. Available from: http://jurnal.poltekkespalu.ac.id/index.php/J IK/article/view/430

71. Astuti NP, Nugroho EGZ, Lattu JC, Potempu IR, Swandana DA. Persepsi Masyarakat terhadap Penerimaan Vaksinasi Covid-19: Literature Review. J Keperawatan [Internet]. 2021 Jul
10;13(3):569-80. Available from: https://journal.stikeskendal.ac.id/index.php/ Keperawatan/article/view/1363

72. Setiati S, Azwar MK. COVID-19 and Indonesia. Acta Med Indones [Internet]. 2020;52(1):84-9. Available from: http://www.actamedindones.org/index.php/i jim/article/view/1426 